\title{
Natural Liquid Dyestuff from Wastewater of Gambier Processing (Uncaria gambir Roxb) as Textile Dye
}

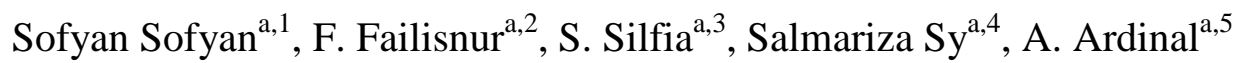 \\ ${ }^{a}$ Institution for Research and Standardization of Industry, Padang,The Ministry of Industry, Indonesia \\ E-mail: ${ }^{1}$ sofyantk84@gmail.com; ${ }^{2}$ failisnur@gmail.com; ${ }^{3}$ silfiabintiarsul@gmail.com; ${ }^{4}$ rizasalma@gmail.com; ${ }^{5}$ ardinal_ok@yahoo.co.id
}

\begin{abstract}
Wastewater of Gambier (Uncaria gambier Roxb) is a byproduct of pressing gambier leaves used for textile dyes. This wastewater cannot be stored for a long time to ease the moldy and rot process. The use of textile dye directly requires several long process steps. The study's purpose was to make a natural liquid dyestuff from gambier wastewater using varying mordant concentrations and test the quality of the dyestuff on cotton fabrics. The gambier wastewater was reacted with the $\mathrm{FeSO}_{4}$ mordant to form a concentrated liquid used directly to dye textiles in a rapid and straightforward process. The study investigated varying the concentration of the $\mathrm{FeSO}_{4}$ mordant from 1 to $5 \%$ (by weight). The reaction between wastewater and mordant was conducted while being stirred at $300 \mathrm{rpm}$ and $70^{\circ} \mathrm{C}$ for 30 minutes. It was generated a dark green liquid dyestuff. The concentration of $\mathrm{FeSO}_{4}$ influenced the color strength $(K / S)$ of the dyestuff and resulted in $K / S$ values from 2.49-3.70. This dyestuff-colored cotton cloth a greenish-grey color. The resulting color depth depended on diluting the dyestuff with $\mathrm{K} / \mathrm{S}$ values ranging from 6.34 to 12.64 . The color fastness against washing, sunlight, and rubbing varied from reasonably good (2-3), good (4), and very good (4-5). It was observed that after a year of storage, the dyestuff retained its color, was stable and showed no visible sign of mold contamination, and was still able to dye the fabric effectively.
\end{abstract}

Keywords - gambier; mordant; liquid dyestuff; Uncaria gambir Roxb; wastewater of gambier.

\section{INTRODUCTION}

The use of natural textile dyes as substitutes for synthetic dyes is growing in popularity. They are seen as eco-friendly, renewable, abundant, nontoxic, and non-allergic [1]-[3]. One source of natural textile dyes is Gambier (Uncaria Gambir Roxb) [4]. Gambier is a natural material obtained from pressing leaves and gambier plant branches [5]-[7]. 80\% of the world's Gambier supply comes from Indonesia [8] and West Sumatra Province, the largest gambier producer, with around 17,000 tons in 2016 [9].

Gambier is a well-known textile dye. When used at 60$70^{\circ} \mathrm{C}$ with a $\mathrm{CaO}$ mordant, it produced a reddish-brown with a K/S value of 19.74. A previous study has found this color to have excellent (4-5) colorfastness on washing $\left(40^{\circ} \mathrm{C}\right)$, on exposure to light, and rubbing [4], where it has been used on cotton, silk, and rayon batik cloth [10] with the best result obtained on silk fabrics. Wastewater seeps out during pressing leaves and branches, containing 25-30\% tannins [11], [12]. Tannins can often be used as textile dyes [5], [13]. However, tannins from this gambier wastewater as dyes are not widely published. Dyeing of textile with gambier wastewater using mordant $\mathrm{CaCO}_{3}, \mathrm{Al}_{2}\left(\mathrm{SO}_{4}\right)_{3}$, and $\mathrm{FeSO}_{4}$ produced various colors [5]. The addition of Sappan wood
(Caesalpinia sappan Linn) has been found to add color variation to the resulting fabric [14].

Gambier wastewater cannot be stored for a long time and quickly grows mold and deteriorates. Direct use as a textile dye is a long, multi-step process. However, when combined with the mordant $\mathrm{FeSO}_{4}$ it can be used directly without pretreatment, simplify, and shortening the coloring process. The resulting dye is more durable and can be used repeatedly. This is one of the benefits of using the gambier liquid dye.

The study's purpose was to make a natural liquid dyestuff from gambier wastewater using varying mordant, investigate the effect of mordant concentration on the dyestuff produced on color cloth, and test the quality of the coloring. Using this method will produce a dyestuff that is ready and easy to use for the coloring process. The application of this natural dyestuff in textile products is the same as using synthetic dyes. Because of its liquid physical form, we only need to dilute it with water according to the desired intensity of textile color. This will change the view of industry parties who think that natural dyes are complicated and take a long time. Moreover, because it comes from an organic natural resource, it will be eco-friendlier and more renewable. 


\section{MATERIALS AND METHODS}

Gambier wastewater was used with mordant $\mathrm{FeSO}_{4}$ and applied to white cotton fabric. Gambier wastewater was taken from the Gambier's pressing location in Siguntur, Pesisir Selatan District, West Sumatra Province, Indonesia. The white cotton fabric used was the production of PT. Primisima, Yogyakarta, Indonesia. $\mathrm{FeSO}_{4}$ used as a mordant was technical grade supplied by $\mathrm{CV}$. Bratachem. The equipment used was a dye bath, stove, strainer 400 mesh, and thermometer.

\section{A. Making the Dyestuff}

Wastewater was filtered with a 400-mesh filter, afterward heated to $70^{\circ} \mathrm{C}$. Varying amounts of the mordant solution of $\mathrm{FeSO}_{4}(1 \%, 2 \%, 3 \%, 4 \%$, or $5 \%)$ were then added according to treatment and then stirred at $300 \mathrm{rpm}$ for 30 minutes mordant dissolved completely. The dyestuff was then ready to use.

\section{B. Dyeing the Cloth}

The dyestuff was used in concentrations of $25 \%$ and $50 \%$ $(\mathrm{v} / \mathrm{v})$. It was applied to the white cotton cloth that had been pre-washed with detergent, rinsed with water then dried. The fabric was heated with the liquid dyestuff solution at $50^{\circ} \mathrm{C}$ for about 10 minutes, then air-dried. Three replications for each mordant concentration and dye dilution were done.

\section{Testing}

The dyestuff was tested for color strength, brightness, and color scale by CIE-Lab method used "Premiere Colorscan" SS 6200. In this study, we tested the dye's functional groups by Fourier Transform Infra-Red (FTIR) testing to see the dominant groups in the dyestuff and the effect of the mordant concentration $\mathrm{FeSO}_{4}$ used on the functional groups of the dyes produced. The dyed fabric was tested for color strength and dye quality, including colorfastness on washing, rubbing, and light exposure.

\section{RESULT AND DISCUSSION}

\section{A. Dyestuff Produced}

The dyestuff produced from the five treatments and control is shown in Figure 1. The color of gambier wastewater without mordant (control) appeared brown. With the addition of mordant, the dyestuff was an almost identical dark green. The results of the color scale measurements of the dyestuff obtained are differences in color strength (K/S), brightness $\left(\mathrm{L}^{*}\right)$, and the chromatic coordinates $\left(\mathrm{a}^{*}\right.$ and $\mathrm{b}^{*}$, corresponding to the position on a chromaticity diagram) as shown in Table I.

$\mathrm{K} / \mathrm{S}$ was positively correlated to the mordant concentration varying from 2.51-3.70. The strongest color came from $5 \%$ mordant and had a K/S of 3.7. All dyestuff solutions had higher values than the unmordanted (control), which had a K/S of 0.66. In gambier liquid dyestuff, mordant is added directly to the coloring agent to improve the color quality. Most natural dyes are not substantive but require mordants to adhere to fibers for colorfastness. Mordants are usually derived from metal salts, including ferrous salts [1], [15]. In this case, the ferrous salt FeSO4 was used as the Fe2- ion from this mordant also reacts with the Gambier phenol group to form a more stable complex, which gives rise to the color. The trials' color and results indicate that $\mathrm{Fe}^{2-}$ ion from $\mathrm{FeSO}_{4}$ produced a moderately good and stable color reaction with gambier liquid dyestuff.

Ferric metal is one of the mordant metals which can increase the color strength of fabric. The K/S value maximum was obtained for coloring cotton yarn using mordant $\mathrm{FeSO}_{4}$ and $\mathrm{CuSO}_{4}$. The maximum of $\mathrm{K} / \mathrm{S}$ values in silk yarn coloring using $T$. catappa and $T$. grandis were obtained with mordant FeSO4 [16], [17]. Other metal salts as mordant react to form different colors, but not all are stable and produce good color strength, so that they are not suitable for use as direct dyes. The use of natural dyes in textiles using mordant metals $\mathrm{Al}_{2}\left(\mathrm{SO}_{4}\right)_{3}, \mathrm{CuSO}_{4}, \mathrm{SnCl}_{2}$, and $\mathrm{FeSO}_{4}$ produced various colors. The maximum color intensity in silk yarn is obtained using mordant salts $\mathrm{Cu}$ (II) and $\mathrm{Fe}$ (II) compared to $\mathrm{Al}(\mathrm{III})$ and $\mathrm{Cu}(\mathrm{II})$ [17].

The mordant methods also influence the color and characteristics produced. This study's dyestuff was made almost like the coloring method using a simultaneous mordant method; mordant was added directly to the coloring agent. The effect of the mordant method on coloring using gambier extract has been observed and found that the post mordant method produced a higher color strength compared to the simultaneous mordant method [18]. A different study reported that the pre-mordant method produces a better color than the post mordant method in silk yarn coloring [17]. It could happen because the treatment of the material to be colored is different.

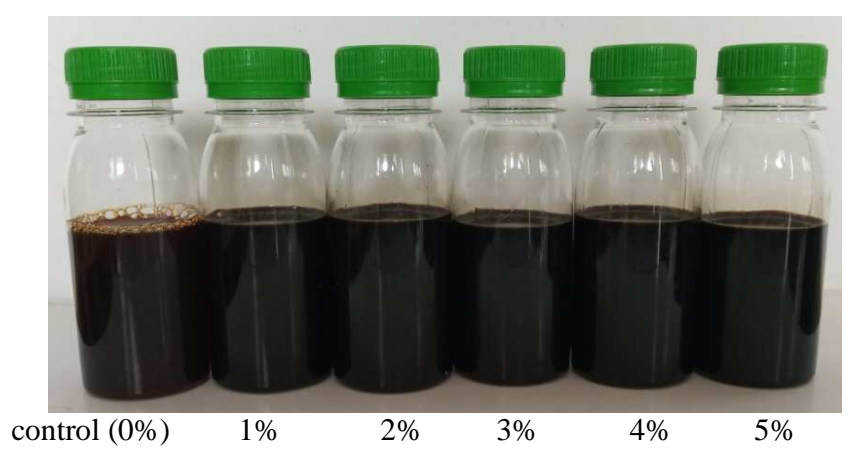

Fig. 1 Natural liquid dyestuff produced with varying concentrations of mordant $\mathrm{FeSO}_{4} 1 \%, 2 \%, 3 \%, 4 \%, 5 \%$, and $0 \%$ (control)

The lightness value of color $\left(\mathrm{L}^{*}\right)$ was found to be inversely proportional to the value of $\mathrm{K} / \mathrm{S}$. The lowest lightness was obtained from a dyestuff with $1 \%$ mordant concentration (28.19), and the highest with 5\% mordant (0.83). This indicates that the higher the mordant concentration, the darker and deeper the color produced of all the dyestuffs trialed. This means the concentration of mordant affects the darkness and lightness of the dyestuff produced.

Chromaticity coordinates $\mathrm{a}^{*}$ and $\mathrm{b}^{*}$ indicate the position of a color on a chromaticity plane where $+\mathrm{a}$ is red and $-\mathrm{a}$ is green, while $+b$ is yellow and $-b$ is blue. Chromaticity coordinates obtained indicate dyestuff produced are between the red and yellow coordinates. The combination of these two colors makes a dye that visually looks dark green. $\Delta \mathrm{E}$ is a color difference. While each dye produced a dark green, the intensity difference can be seen from the color difference 
value. Using the $1 \%$ mordant as a reference, the largest $\Delta \mathrm{E}$ comes from the 5\% mordant dyestuff (36.92), indicating the relationship between mordant concentration and color.

Gambier wastewater is one of the most easily damaged materials that will be fermented and acidic in just 2 or 3 days, and even mold growth can be seen within a week of storage. To find out the durability of the stored dyestuff produced, we observed the dyestuff for one year. After one year of room temperature storage, the dyestuff solution appeared stable, and there was no mold growth. The results of the coloring test show that the used dyestuff can still be used to dye textiles. This indicates that this dyestuff could be stored for longer than gambier wastewater, which grows moldy in just a few days.

TABLE I

Color Scale Of The Natural Liquid Dyestuff Produced With VARYING CONCENTRATIONS OF MORDANT $\mathrm{FeSO}_{4} 1 \%, 2 \%, 3 \%, 4 \%, 5 \%$, AND 0\% (CONTROL)

\begin{tabular}{|l|l|l|l|l|l|}
\hline $\begin{array}{l}\mathbf{F e S O}_{4} \\
\text { concentration }\end{array}$ & $\mathbf{K} / \mathbf{S}$ & $\mathbf{L}^{*}$ & $\mathbf{a}^{*}$ & $\mathbf{b}^{*}$ & $\mathbf{} \mathbf{E}$ \\
\hline $1 \%$ & 2.51 & 28.19 & 9.72 & 23.07 & Target \\
\hline $2 \%$ & 2.52 & 16.88 & 6.24 & 10.47 & 17.28 \\
\hline $3 \%$ & 3.22 & 3.74 & 3.28 & 2.36 & 32.68 \\
\hline $4 \%$ & 3.52 & 1.02 & 1.06 & 0,25 & 36.53 \\
\hline $5 \%$ & 3.70 & 0.83 & 0.87 & -0.09 & 36.92 \\
\hline control $(0 \%)$ & 0.66 & 86.95 & 2.27 & 27.60 & 27.69 \\
\hline
\end{tabular}

\section{B. FTIR Measurement of Dyestuff}

The FTIR test results are shown in Figure 2. Each mordant concentration has the same functional groups. An absorption peak is visible at wave number $3339.13 \mathrm{~cm}^{-1}$, which corresponds to the $\mathrm{O}-\mathrm{H}$ group. This functional group is the most dominant in gambier dyes because the main colorant content of gambier waste is from tannins, complex polyphenolic compounds containing many O-H groups [19][21]. The mordant concentration did not significantly influence the intensity of the absorption peaks. The wavenumbers $\left(3337.02 \mathrm{~cm}^{-1}-3339.62 \mathrm{~cm}^{-1}\right)$ of the absorption peaks are very similar to the intensities of these peaks. The dominant peak at wave number $3600-3200 \mathrm{~cm}^{-1}$ corresponds to a phenol group with an O-H group [22].

This pattern resembles that found from a stamp ink made from Gambier using $\mathrm{NaOH}$ and $\mathrm{Al}_{2}\left(\mathrm{SO}_{4}\right)_{3}$ complexes. Gambier tannin absorption peaks at wavenumber 3314.65 $\mathrm{cm}^{-1}$ due to the O-H groups in the phenol compound [23]. FTIR peak was found at wave number $3356.25 \mathrm{~cm}^{-1}$ corresponding to O-H groups in dry tannin extract [24]. An O-H group stretching vibration peak for lawsonia inermis at wave number $3376 \mathrm{~cm}^{-1}$ [25].

Absorption peaks were also seen at wave number 1627.98 $\mathrm{cm}^{-1}-1633.18 \mathrm{~cm}^{-1}$ in gambier wastewater and the dyestuff. The absorption band at $1633 \mathrm{~cm}^{-1}$ is associated with $\alpha, \beta$ unsaturated carbonyl bands [25]. Quinone carbonyl bands usually appear in the range of 1655-1690 $\mathrm{cm}^{-1}$ [25]. Aromatic ring $\mathrm{C}=\mathrm{C}$ vibration is indicated by a peak in the region 1622.78-1448.82 $\mathrm{cm}^{-1}$ [25], [26] and in the regions $1617,1510,1444 \mathrm{~cm}^{-1}$ [24].

In the wavenumber area of $1066 \mathrm{~cm}^{-1}-1097 \mathrm{~cm}^{-1}$ the mordanted dyestuff was found to have different absorption intensity than the gambier wastewater with absorption intensity $46.36-57.80 \%$, indicating the presence of $\mathrm{C}-\mathrm{O}-\mathrm{C}$ ester functional groups. Gambier wastewater has a lower absorption intensity of $79.02 \%$ in the wavenumber area $1135.68 \mathrm{~cm}^{-1}$, which corresponds to ester functional groups. The increased presence of ester groups in the mordanted dyestuff is thought to be due to hydrolyzed tannins' formation due to the presence of ester bonds between hydroxyl groups and carbonyl groups [21].

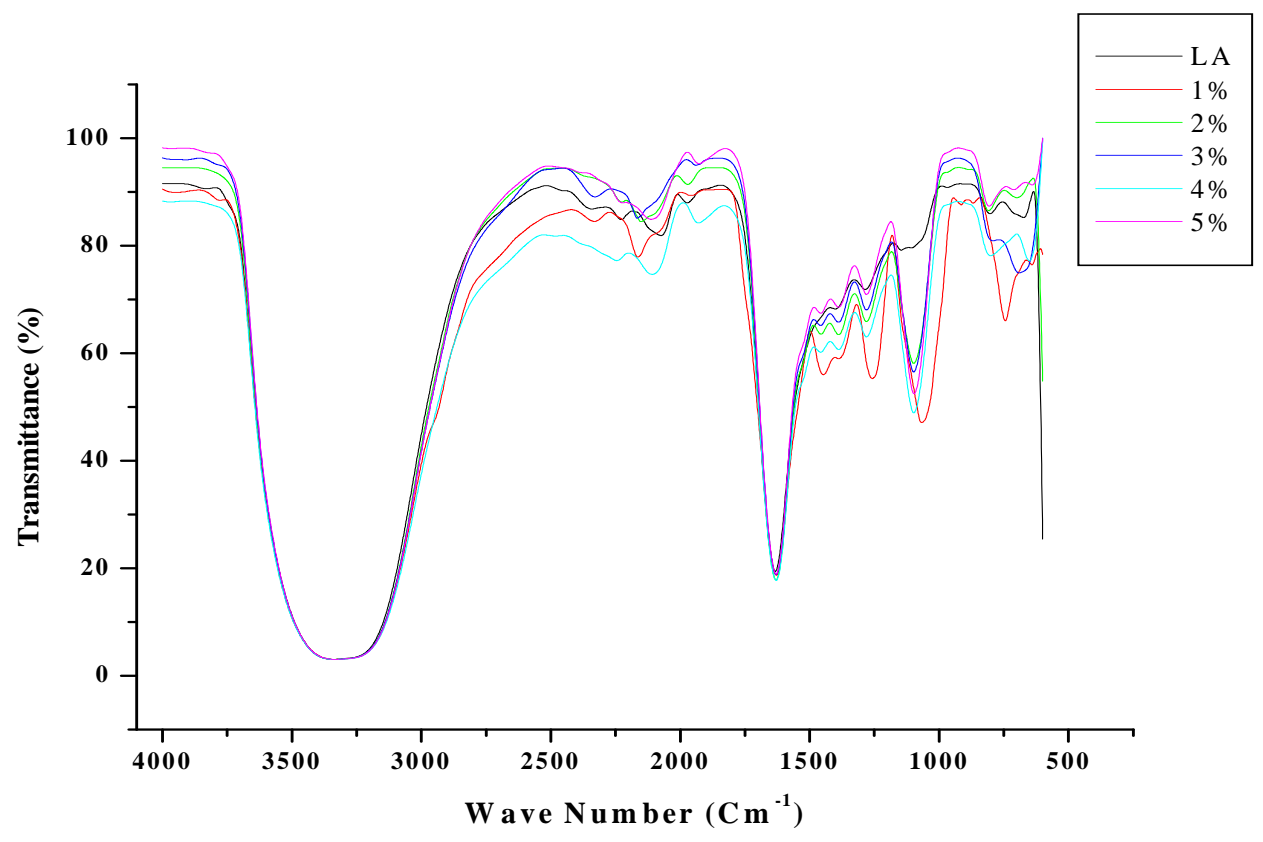

Fig. 2 FTIR spectra of the natural liquid dyestuff produced with varying concentrations of mordant $\mathrm{FeSO}_{4} 1 \%, 2 \%, 3 \%, 4 \%, 5 \%$, and $0 \%$ as a control (LA). 


\section{Result of Cotton Fabric Dyeing}

The application of dyestuff on fabric is necessary to see whether it is suitable for textile dyes. Some studies do coloring with separate mordant processes, either with pre, simultaneous, or post mordant. Direct coloring with natural dyes is rarely done. The colors of the dyed fabric in this study are shown in Table II. All the fabrics that had been colored visually had a similar color with a greenish-gray color except for the control. Apart from the unmordanted sample that was brown, samples dyed greenish-gray. However, they are different from chromaticity coordinates $\left(\mathrm{L}^{*}, \mathrm{a}^{*}\right.$, and $\left.\mathrm{b}^{*}\right)$. Higher $\mathrm{FeSO}_{4}$ mordant concentrations result in a stronger color of dyed fabric, as shown by each sample's color values. All mordanted samples had stronger color values than the unmordanted control. It was also found that using gambier waste mordanted with $\mathrm{FeSO}_{4}$ resulted in similar greenish-grey colors [5]. The previous studies used gambier dye with $\mathrm{FeSO}_{4}$ as a post mordant with visually similar results [27], [28]. Coloring used Bougainvillea with alum and ferrous mordant resulting in a green color [29].

Dye concentration influenced the intensity of the resulting color, with the more concentrated dye producing a more intense color for each mordant concentration used. The most intense color came from the $5 \%$ mordant with a $\mathrm{K} / \mathrm{S}$ and $\mathrm{L}^{*}$ value of 11.87 and 32.25 when used at $25 \%$ and 12.64 and 30.77 at $50 \%$, respectively. As with the dyestuff, brightness (L*) was inversely proportional to color strength K/S (Table II).

Mordant influences the color hue and characteristics of the fabric as well. $\mathrm{CaO}$ mordant is used to dye cotton yarn with liquid waste from a gambier dye produced a brown color with different intensity depending on the treatment and dyeing time [28]. Some kind and method of mordants for coloring cotton fabric was compared using the simultaneous mordant method [18]. The colors produced with $\mathrm{Al}_{2}\left(\mathrm{SO}_{4}\right)_{3}$, $\mathrm{CaO}$, and $\mathrm{FeSO}_{4}$ were light brown, moderate brown, and brownish-black, respectively [18].

TABLE II

Dye Result and Color Properties of Dyed CotTon Fabric With NATURAl LiQuid DyestufF Produced with Varying ConcentRations OF MORDANT $\mathrm{FeSO}_{4} 1 \%, 2 \%, 3 \%, 4 \%, 5 \%$, AND 0\% (CONTROL) USING DYE CONCENTRATION 25\% AND 50\%.

\begin{tabular}{|c|c|c|c|c|c|c|c|}
\hline Dye concentration & mordant & Resulting color & $\mathbf{K} / \mathbf{S}$ & $\mathbf{L}^{*}$ & $\mathbf{a}^{*}$ & $\mathbf{b}^{*}$ & $\Delta \mathbf{E}$ \\
\hline \multirow{5}{*}{$25 \%$} & $1 \%$ & & 6.98 & 41.96 & 3,74 & 12,47 & Target \\
\hline & $2 \%$ & & 7.85 & 39.11 & 3.54 & 11.50 & 3.02 \\
\hline & $3 \%$ & & 7.53 & 39.25 & 3.43 & 11.33 & 2.96 \\
\hline & $4 \%$ & & 10.18 & 34.92 & 3.45 & 11.17 & 7.17 \\
\hline & $5 \%$ & & 11.87 & 32.25 & 3.59 & 10.65 & 9.86 \\
\hline \multirow{5}{*}{$50 \%$} & $1 \%$ & & 6.34 & 44.20 & 3.32 & 13.08 & 2.36 \\
\hline & $2 \%$ & & 8.43 & 38.16 & 3.33 & 11.44 & 3.96 \\
\hline & $3 \%$ & & 9.71 & 34.76 & 3.45 & 10.41 & 7.49 \\
\hline & $4 \%$ & & 11.81 & 32.35 & 3.25 & 10.38 & 9.84 \\
\hline & $5 \%$ & & 12.64 & 30.77 & 3.11 & 9.72 & 11.54 \\
\hline \multicolumn{2}{|c|}{ Control (without mordant) } & & 4.025 & 62.36 & 4.17 & 20.14 & 21.79 \\
\hline
\end{tabular}

\section{Color Fastness of Cotton Fabric}

It is essential to look at the quality of the fabric colored as well, especially the colorfastness properties, whether the dye absorbs into the fabric fiber and is adequately bonded. Dyed fabrics were analyzed for colorfastness with washing, light exposure, and rubbing, as shown in Table III and Table IV. The average colorfastness for fading is $2-3$, while color stain on acetate, cotton, polyamide, polyester, acrylic, and wool averaged 4-5. Results show that mordant concentration and dye concentration do not affect colorfastness. Some studies had been done on post mordant dyeing method where the mordant was added after dying. One research studied the fastness and color intensity of post-mordanted gambier dyed silk fabrics and found colorfastness on washing 4 and with light exposure 3-4 [4]. The color fastness of fabrics dyed 
with gambier dye and post mordanted with several different mordants was 3 for washing and 3-4 for light exposure [5].

Colorfastness against light exposure of the dyed cotton appeared to be good with a value of 4 for $25 \%$ dyestuff concentration and 1-2\% mordant. However, this dropped to 3-4 with 50\% dyestuff concentration and 4-5\% mordant. This shows that treatment with low mordant and dye concentrations provided better colorfastness to light than higher concentrations. Some natural dyes have poor light color fastness [30]-[32]. However, this natural liquid dye produces fairly good colorfastness. Concentrations of dyestuff $(25 \%$ and $50 \%)$ and mordant $(1-5 \%)$ did not significantly affect color fastness against rubbing. It can be seen from Table IV that the color fastness for rubbing for the dry cotton fabric was around 4-5 and slightly lower on wet cotton fabric (between 4 and 4-5).

TABLE III

COLOR FASTNESS ON WASHING OF COLORED COTTON FABRIC WITH NATURAL LIQUID DYESTUFF PRODUCED WITH VARYING CONCENTRATIONS OF MORDANT $\mathrm{FeSO}_{4} 1 \%, 2 \%, 3 \%, 4 \%, 5 \%$, AND 0\% (CONTROL) USING DYE CONCENTRATION 25\% AND 50\%.

\begin{tabular}{|c|c|c|c|c|c|c|c|c|}
\hline \multirow{3}{*}{$\begin{array}{l}\text { Dye } \\
\text { concentration }\end{array}$} & \multirow{3}{*}{$\begin{array}{l}\text { Mordant } \\
\text { concentration }\end{array}$} & \multicolumn{7}{|c|}{ Colorfastness of fabric with washing at $40^{\circ} \mathrm{C}$} \\
\hline & & \multirow{2}{*}{ Color change } & \multicolumn{6}{|c|}{ Color staining } \\
\hline & & & Acetate & Cotton & Polyamide & Polyester & Acrylic & Wool \\
\hline \multirow{5}{*}{$25 \%$} & $1 \%$ & $2-3$ & $4-5$ & $4-5$ & $4-5$ & $4-5$ & $4-5$ & $4-5$ \\
\hline & $2 \%$ & $2-3$ & $4-5$ & 4 & $4-5$ & $4-5$ & $4-5$ & $4-5$ \\
\hline & $3 \%$ & $2-3$ & $4-5$ & $4-5$ & $4-5$ & $4-5$ & $4-5$ & $4-5$ \\
\hline & $4 \%$ & $2-3$ & $4-5$ & $4-5$ & $4-5$ & $4-5$ & $4-5$ & $4-5$ \\
\hline & $5 \%$ & $2-3$ & 4 & $4-5$ & $4-5$ & $4-5$ & $4-5$ & $4-5$ \\
\hline \multirow{5}{*}{$50 \%$} & $1 \%$ & 3 & $4-5$ & 4 & $4-5$ & $4-5$ & $4-5$ & $4-5$ \\
\hline & $2 \%$ & $2-3$ & $4-5$ & 4 & $4-5$ & $4-5$ & $4-5$ & $4-5$ \\
\hline & $3 \%$ & $2-3$ & $4-5$ & $4-5$ & $4-5$ & $4-5$ & $4-5$ & $4-5$ \\
\hline & $4 \%$ & $2-3$ & $4-5$ & $4-5$ & $4-5$ & $4-5$ & $4-5$ & $4-5$ \\
\hline & $5 \%$ & $2-3$ & $4-5$ & 4 & $4-5$ & $4-5$ & $4-5$ & $4-5$ \\
\hline \multicolumn{2}{|c|}{ Control (without mordant) } & $2-3$ & $4-5$ & $4-5$ & $4-5$ & $4-5$ & $4-5$ & $4-5$ \\
\hline
\end{tabular}

TABLE IV

COLOR FASTNESS ON LIGHT EXPOSURE AND RUBBING OF COLORED COTTON FABRIC WITH NATURAL LIQUID DYESTUFF PRODUCED WITH VARYING CONCENTRATIONS OF MORDANT $\mathrm{FeSO}_{4} 1 \%, 2 \%, 3 \%, 4 \%, 5 \%$, AND 0\% (CONTROL) USING DYE CONCENTRATION 25\% AND 50\%.

\begin{tabular}{|l|l|l|l|l|}
\hline \multirow{4}{*}{$\begin{array}{l}\text { Dye } \\
\text { concentration }\end{array}$} & \multirow{2}{*}{$\begin{array}{l}\text { Mordant } \\
\text { Concentration } \\
\text { fastness } \\
\text { to light }\end{array}$} & $\begin{array}{l}\text { Colorfastness to } \\
\text { rubbing }\end{array}$ \\
\cline { 3 - 5 } & & $\begin{array}{l}\text { Dry } \\
\text { cotton } \\
\text { fabric }\end{array}$ & $\begin{array}{l}\text { Wet } \\
\text { cotton } \\
\text { fabric }\end{array}$ \\
\hline \multirow{5}{*}{$25 \%$} & $1 \%$ & 4 & $4-5$ & 4 \\
\cline { 2 - 5 } & $2 \%$ & 4 & $4-5$ & $4-5$ \\
\cline { 2 - 5 } & $3 \%$ & $3-4$ & $4-5$ & $4-5$ \\
\cline { 2 - 5 } & $4 \%$ & $3-4$ & $4-5$ & 4 \\
\cline { 2 - 5 } & $5 \%$ & $3-4$ & $4-5$ & $4-5$ \\
\hline \multirow{5}{*}{$50 \%$} & $1 \%$ & 4 & $4-5$ & 4 \\
\cline { 2 - 5 } & $2 \%$ & 4 & $4-5$ & $4-5$ \\
\cline { 2 - 5 } & $3 \%$ & 4 & $4-5$ & 4 \\
\cline { 2 - 5 } & $4 \%$ & $3-4$ & $4-5$ & 4 \\
\cline { 2 - 5 } & $5 \%$ & $3-4$ & $4-5$ & 4 \\
\hline Control (without mordant) & $3-4$ & $4-5$ & 4 \\
\hline
\end{tabular}

\section{CONCLUSIONS}

Liquid waste of gambier processing, which was reacted with mordant ferric sulfate, produced a dark green color in liquid textile dyestuff. The mordant concentration affected the color strength of the dyestuff. The more significant the concentration, the more the color strength. The maximum color strength was achieved using FeSO4 5\% in the dyestuff with a K/S value of 12.64 . The resulting color direction was similar with different color coordinates $\left(\mathrm{L}^{*} \mathrm{a}^{*} \mathrm{~b}^{*}\right)$ for each mordant concentration. The most dominant functional group in the dyestuff was $\mathrm{O}-\mathrm{H}$ groups, which were complexes polyphenolic compounds.

Application test of the dyestuff to the cotton fabrics produced a greenish-gray color. The cotton fabrics' colorfastness against washing, light, and rubbing of the fabrics ranged from good (4) to very good (4-5). Dye concentration influenced the color intensity of the cotton fabrics. $50 \%$ of liquid dyestuff generated older greenish-gray color than $25 \%$. The dyestuff appeared to remain stable after one year of room temperature storage with no visible mold growth. We still need to observe the dyestuff's stability to see its effectiveness and feasibility in textile coloring.

\section{ACKNOWLEDGMENT}

The authors thank the Ministry of Industry of Republic of Indonesia, for funding this research through the Institution for Research and Standardization of Industry - Padang budget.

\section{REFERENCES}

[1] A. K. Samanta and P. Agarwal, "Application of natural dyes on textiles," Indian J. Fibre Text. Res., vol. 34, no. 4, pp. 384-399, 2009.

[2] T. Alemayehu and Z. Teklemariam, "International Journal of Application of Natural Dyes on Textile: A Review," Int. J. Res. Granthaalayah I, vol. 2, no. 2, pp. 61-68, 2014.

[3] S., Adeel, F., Rehman, R., Hanif, M., Zuber, E., Haq, M., Muneer, 
"Ecofriendly dyeing of UV-irradiated cotton using extracts of Acacia nilotica bark (Kikar) as source of quercetin," Asian J. Chem. 26 (3), 830-834, 2014.

[4] F. Failisnur and S. Sofyan, "Sifat tahan luntur dan intensitas warna kain sutera dengan pewarna alam gambir (Uncaria gambir Roxb) pada kondisi pencelupan dan jenis fiksator yang berbeda," J. Litbang Indsutri, vol. 4, no. 1, pp. 1-8, 2014.

[5] S. Sofyan, F. Failisnur, and S. Sy, "Pengaruh perlakuan limbah dan jenis mordan kapur, tawas, dan tunjung terhadap mutu pewarnaan kain sutera dan katun menggunakan limbah cair gambir (Uncaria gambir Roxb)," J. Litbang Indsutri, vol. 5, no. 2, pp. 79-89, 2015.

[6] Sabarni, "Teknik pembuatan gambir (Uncaria gambir Roxb) secara tradisional," J. Islam. Sci. Technol., vol. 1, no. 1, pp. 105-112, 2015.

[7] A. H. Nasution, R. W. Asmarantaka, and L. M. Baga, "Sistem pemasaran gambir di Sumatera Barat (kasus di Kecamatan Kapur IX, Kabupaten Lima Puluh Kota)," SEPA, vol. 12, no. 1, pp. 1-10, 2015.

[8] E. G. Said, K. Syamsu, E. Mardliyati, and A. Herryandie, Agroindustri bisnis gambir Indonesia. 2009.

[9] S. B. P. Statistics, "Sumatera Barat Province in Figure." 2018.

[10] S. Sofyan and F. Failisnur, "Gambir (Uncaria gambir Roxb) sebagai pewarna alam kain batik sutera, katun, dan rayon," J. Litbang Indsutri, vol. 6, no. 2, pp. 89-98, 2016.

[11] H. Muchtar, "Pengaruh penambahan garam natrium dalam proses pengendapan limbah pengolahan gambir terhadap rendemen tanin," $J$. Litbang Ind., vol. 3, no. 1, pp. 59-65, 2013.

[12] G. Yeni, D. Syafruddin, A. Kasim, and Amos, "Pengujian kemampuan daya samak cube black dan limbah cair terhadap mutu kulit tersamak," J. litbang Ind., vol. 6, no. 1, pp. 73-82, 2016.

[13] S., Adeel, S., Ali, I., A., Bhatti, F., Zsila, "Dying of catton fabric using pomegranate (Punica granatum) aqueous extract," Asian Journal of Chemstry, vol. 21 no. 5, pp. 3493-3499, 2009

[14] Failisnur, Sofyan, and W. Hermianti, "Pemanfaatan limbah cair pengempaan gambir untuk pewarnaan kain batik," J. Litbang Ind., vol. 7, no. 1, pp. 19-28, 2017.

[15] L. M. Wangatia, K. Tadesse, and S. Moyo, "Mango bark mordant for dyeing cotton with natural dye : fully eco-friendly natural dyeing," Int. J. Text. Sci., vol. 4, no. 2, pp. 36-41, 2015 .

[16] S. Baliarsingh, P. C. Behera, J. Jena, T. Das, and N. B. Das, "UV reflectance attributed direct correlation to colour strength and absorbance of natural dyed yarn with respect to mordant use and their potential antimicrobial efficacy," J. Clean. Prod., vol. 102, pp. 485492, 2015.

[17] A. K. Prusty, T. Das, A. Nayak, and N. B. Das, "Colourimetric analysis and antimicrobial study of natural dyes and dyed silk," $J$. Clean. Prod., vol. 18, pp. 1750-1756, 2010.

[18] F. Failisnur, S. Sofyan, A. Kasim, and T. Angraini, "Study of cotton fabric dyeing process with some mordant methods by using gambier
(Uncaria gambir Roxb) extract," vol. 8, no. 4, pp. 1098-1104, 2018.

[19] G. Yeni, K. Syamsu, E. Mardliyati, and H. Muchtar, "Penentuan teknologi proses pembuatan gambir murni dan katekin terstandar dari gambir," J. Litbang Indsutri, vol. 7, no. 1, pp. 1-10, 2017.

[20] R. Sri Irianty and S. R. Yenti, "Pengaruh perbandingan pelarut etanol-air terhadap kadar tanin pada sokletasi daun gambir (Uncaria gambir Roxb)," Sagu, vol. 13, no. 1, pp. 1-7, 2014.

[21] P. Puspita Sari, W. Susanah Rita, and N. Puspawati, "Identifikasi dan uji aktivitas senyawa tanin dari ekstrak daun trembesi (Samanea Saman (Jacq.) Merr) sebagai antibakteri Escherichia Coli (E. Coli)," J. Kim., vol. 9, no. 1, pp. 27-34, 2015.

[22] T. Maharani, D. Sukandar, and S. Hermanto, "Karakterisasi senyawa hasil isolasi dari ekstrak etil asetat daun namnam (Cynometra Cauliflora L.) yang memiliki aktivitas antibakteri," J. Kim. Val., vol. 2, no. 1, pp. 55-62, 2016.

[23] S. Silfia, F. Failisnur, and S. Sofyan, "Analisis gugus fungsi, distribusi, dan ukuran partikel tinta stempel dari ekstrak gambir (Uncaria gambir Roxb) dengan senyawa pengomplek $\mathrm{NaOH}$ dan $\mathrm{Al}_{2}\left(\mathrm{SO}_{4}\right)_{3}$, J. Litbang Ind., vol. 8, no. 1, pp. 31-38, 2018.

[24] A. I. Rosyida, "Peningkatan kualitas kayu merbau (Intsia bijuga): kompleksasi logam $\mathrm{Cu}(\mathrm{II}), \mathrm{Fe}(\mathrm{III})$ dan $\mathrm{Zn}$ (II) oleh senyawa tanin,” in Prosiding Kimia FMIPA, 2009, pp. 1-6.

[25] F. Zulkifli et al. "The effect of concentration of Lawsonia inermis as a corrosion inhibitor for aluminum alloy in seawater," $A d v$. Phys. Chem., vol. 2017, 2017.

[26] H. M. Hajar, F. Zulkifli, M. G. M. Sabri, A. Fitriadhy, and W. B. W. Nik, "Lawsonia inermis performance as corrosion inhibitor for mild steel in seawater," Int. J. Chem Tech Res., vol. 9, no. 08, pp. 600-608, 2016

[27] F. Failisnur and S. Sofyan, "Pengaruh suhu dan lama pencelupan benang katun pada pewarnaan alami dengan ekstrak gambir (Uncaria gambir Roxb)," J. Litbang Indsutri, vol. 6, no. 1, pp. 25-37, 2016.

[28] S. Sofyan and F. Failisnur, "Reuse of liquid waste from textile dyeing with natural dyes gambier (Uncaria gambir Roxb.) for cotton yarn,” ARPN J. Eng. Appl. Sci., vol. 12, no. 18, pp. 5313-5318, 2017.

[29] J. N. Chakraborty, "Fundamentals and practices in colouration of textiles," pp. 233-261, 2014.

[30] S. S. Kulkarni, A. V Gokhale, U. M. Bodake, and G. R. Pathade, "Cotton dyeing with natural dye extracted from pomegranate (Punica granatum) peel,” Univers. J. Environ. Res. Technol., vol. 1, no. 2, pp. 135-139, 2011.

[31] D. Cristea and G. Vilarem, "Improving light fastness of natural dyes on cotton yarn," Dye. Pigment., vol. 71, pp. 39-46, 2006.

[32] P. Nattaya, N. Monthon, S. Buppha, N. Nootsara, R. Nattadon, and M. Rattanapol, "Silk fabric dyeing with natural dye from mangrove bark (Rhizophora apiculata Blume) extract," Ind. Crops Prod., no. 49, pp. 122-129, 2013. 